\title{
CLUSTER OF COUNTRIES ANALYSIS BY RESPONSIBLE COMPETITIVENESS, NATIONAL COMPETITIVENESS AND CORRUPTION
}

\author{
HERCIU Mihaela
}

\begin{abstract}
:
The Global Competitiveness Report, the State of Responsible Competitiveness and the Global Corruption Barometer elaborate annually a countries ranking that emphasize the progress or regress of each country. Using this reports the paper try to make a clusters analysis of world country by responsible competitiveness, national competitiveness and corruption. The main idea of this paper is to split the countries in three categories of clusters - innovators, asserters and beginners - in relation between responsible competitiveness and national competitiveness - and - stars, asserters and beginners - in relation between corruption and national competitiveness. Within the three clusters, countries may be able to improve their performance through real and suitable policies.
\end{abstract}

Keywords: cluster, responsible competitiveness, national competitiveness, corruption

Clusters are not only a reality of economies across Europe: increasingly they are also an important policy lever on different geographic levels. Interest in cluster has grown because they are a leverage point for action, not just a description on economic reality.

Clusters have become the focal point of many new policy initiatives in the last few years, in Europe as elsewhere around the globe. The challenge set out by the Lisbon European Council in 2000 to make Europe "the worlds most competitive and dynamic knowledge based economy" in particular has sparked interest in new approaches to economic policy for competitiveness. Mobilizing the potential of clusters is seen as critical to reach this ambitious goal (See Christian Ketels, European Clusters, Structural Change in Europe 3 - Innovative City and Business Regions, Hagbarth Publications, 2004).

Michael Porter defines clusters as geographically proximate groups of interconnected companies and associated institutions in a particular field, linked by commonalities and complementarities. Clusters are important, because they allow companies to be more productive and innovative than they could be in isolation. 
And clusters are important because they reduce the barriers to entry for new business creation relative to other locations (See Michael Porter, Clusters and Competition, Harvard Business School Press, 2008). They can only play this role, because the firms and institutions in a particular cluster share four critical characteristics:

$>$ Proximity; they need to be sufficiently close in space to allow any positive spillovers and the sharing of common resources to occur

$>$ Linkages; their activities need to share a common goal, for example, final market demand, for them to be able to profit from proximity and interaction

$>$ Interactions; being close and working on related issues is not enough - for positive cluster effects to occur some level of active interaction has to be present

$>$ Critical mass; finally, there needs to be sufficient number of participants present for the interactions to have a meaningful impact on companies' performance.

Understanding the importance of these four dimensions is much more important than defining specific benchmarks along them that a group of firms and institutions has to meet to be called a cluster.

While clusters are part of regional economies in countries across the globe and at all stages of economic development, there are indications that they might be particular important for understanding and addressing the economic challenges that Europe is facing. Many Europeans are concerned that their prosperity, productivity, and innovation levels fail to keep pace with the United States and increasingly with competitors from other parts of the world like Asia.

While the overall levels of skills, infrastructure, and institutional capacity in Europe seem to be on par or even better than elsewhere in the world, many researchers have identified rules and regulations that hamper flexibility, for example on the labour market, or reduce incentives, for example through high tax rates, as potential reasons for the European performance gap.

The recent work on clusters and competitiveness suggests that differences in regional specialization patterns across cluster categories could be an additional, potentially very powerful driver of this gap. Regional clusters enable companies to reach higher levels of productivity and be more innovative - this is what the available research indicates. If European regions suffer from weaker regional clusters and cluster portfolios than their peers elsewhere in the world, this might be an important factor keeping them behind in global competition (See Ketels, Christian, Solvell, Orjan, Clusters in the EU-10 new member countries).

\section{Cluster analysis by responsible competitiveness and national competitiveness}

Comparing higher-ranking countries such as Belgium, Malaysia and Costa Rica with lower ranking countries like Paraguay, Pakistan and Mali has limited policy implications, as with other wide-angle lens international indexes like the Human Development Index and the World Economic Forum's Competitiveness Indexes. Examining sub-sets of countries is more helpful. 
This paper tries to reveal a statistically-robust set of three clusters of countries, broadly distinguished by their stage of development. What these clusters show is that there can be no cookie-cutter approach to building responsible competitiveness. Countries need to design their own strategies, blending business action, policy drivers and social enablers in the most effective and appropriate combination for their stage of development. Nevertheless, some generalisations are possible for the three broad clusters of countries (See Zadek, Simion, The State of Responsible Competitiveness, AccountAbility, 2007).

Beginners (cluster three): this cluster of lowest scorers is made up of 63 countries, or $59 \%$ of the total list. The largest countries to fall into this cluster include China, Bangladesh, the Russian Federation, Brazil, Turkey and Mexico. Many of these countries have already signalled a commitment to responsibility through signing and ratifying international treaties, and other policy drivers, but are struggling to implement the basics, like worker health and safety and freedom to organise among businesses, on one hand, and focus on demonstrating progress on meeting international quality, labour and environmental standards, and so are building their capacity to capture market share in the global supply chains of more quality-conscious brands and consumers, on the other hand.

Asserters (cluster two): this cluster is made up of $\mathbf{2 4}$ countries, just under a quarter of the total list (22\%). Countries asserting their responsibility credentials range from Spain and Italy to the United Arab Emirates. Asserters are countries moving from the back foot to the front foot, seizing opportunities in responsible competitiveness. Some of them, like Chile and South Africa, are actively engaged in developing and promoting international standards that will provide them with a competitive advantage. Some Asserters are building national brands associated with responsible business and government practices to attract foreign direct investment and promote a first generation of global product and corporate brands. For many Asserters, a vibrant civil society environment - challenging business but ready to collaborate to find solutions - is a critical element in advancing the broader national project.

Innovators (cluster one): this cluster of highest scorers is made up of $\mathbf{2 0}$ countries and the list is dominated by Europe, followed by other OECD countries $(19 \%)$. Innovators are working to embed responsibility into the core of their domestic economies, stewarded by relatively wellenforced statutory regulation, well-designed corporate responsibility strategies, reinforced in most instances by strong NGOs, media watchdogs and consumers demanding responsible new products. Beyond this, knowledge-based innovation provides the leading edge of all of these economies. Sustained innovation in the context of scarce and highly mobile talent requires flexible working conditions, and dynamic, trusted public as well as private institutions. It also demands attention to detail, cascading responsibility into SMEs and overseas investments as well as large domestic firms. For Innovators, responsibility competitiveness is no longer an add-on, but the heart of the economic model.

The Responsible Competitiveness Index - $\mathrm{RCl}$ is not, then, so much a league table of winners and losers, but a tool for diagnosing countries' progress and 
potential in developing their economies and enabling institutions to take advantage of new sources of economic opportunity at ever-higher levels in the value chain (See Zadek, Simion, The State of Responsible Competitiveness, AccountAbility, 2007).

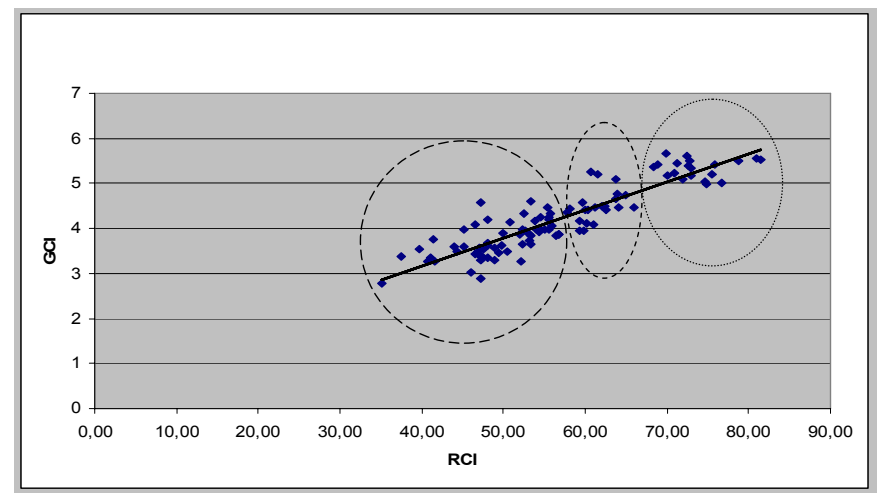

Fig. 1 Identifying clusters of countries by Responsible Competitiveness and National Competitiveness

Within the three clusters, countries may be able to improve their performance along with the organic process of development. But the $\mathrm{RCl}$ shows that being a low scorer is not a 'natural' phenomenon to be waited out until prosperity moves one up the scale. Quite the reverse, the $\mathrm{RCl}$ is a measure of the effectiveness of the combined forces of business strategies and practices and public policies in advancing a country's economic position and role in global markets. It provides a lens for identifying the crucial priorities for each country, region, city or community to get right in order to advance from one cluster to the next higher up the value chain.

\section{Cluster analysis by responsible competitiveness and corruption}

Corruption on the part of governments, the private sector and citizens affects development initiatives at their very root by skewing decision-making, budgeting and implementation processes. When these actors abuse their entrusted power for private gain, corruption denies the participation of citizens and diverts public resources into private hands. The poor find themselves at the losing end of this corruption chain without state support and the services they demand (See Poverty and Corruption, Transparency International, working paper, no. 2, 2008).

The Global Corruption Barometer 2007 shows that the general public continues to view parliaments and political parties as the institutions most tainted by corruption around the world, while the direct experience of those polled points to highest levels of bribery in the police and the judiciary. The result is that key institutions in society, in particular institutions central to the integrity and accountability of government, are compromised. There can be little doubt that corruption undermines the legitimacy of government and those who govern in many countries.

Worldwide, the general consensus is that government efforts to stop corruption are not effective and that corruption will increase in the near future. The results of the Global Corruption Barometer 2007 show that governments need to work harder to 
clean up basic services and to prove to their constituencies that they are committed to fighting corruption in word and deed. But governments are not the only group responsible for making anticorruption initiatives effective. The Global Corruption Barometer 2007 reveals that views and experiences of corruption among ordinary people vary, as corruption has many faces around the world. Anti-corruption strategies need to reflect these crucial differences at country level, matching solutions to local concerns and problems. It is urgent that anti-corruption reforms create results that have real impact on people's lives and that offer people a future where corruption no longer robs them of opportunities - or hope (See Report on the Global Corruption Barometer, Transparency International, 2007).

This part of paper analyzes the clusters of countries by responsible competitiveness and corruption in order to emphasize three groups of countries beginners, asserters and stars.

Beginners (cluster three): this cluster of lowest scorers is made up of 63 countries, or $59 \%$ of the total list. In this group we find out the most corrupted countries and, also, the countries that take no effort to improve responsible competitiveness. The largest countries to fall into this cluster include Poland, Romania, China, India - in the superior part and Venezuela, Guinea, Haiti - in the inferior part.

Asserters (cluster two): this cluster is made up of $\mathbf{2 4}$ countries. Countries from this group assert their anti-corruption policies by implementing anti-corruption strategies at public level, private level and citizen level. In this cluster are countries like: Spain, Estonia, Taiwan, United Arab Emirates.

Stars (cluster one): this cluster of highest scorers is made up of $\mathbf{2 0}$ countries and the list is dominated by Nordic countries of Europe. Also, from this cluster take part New Zealand, Canada, Australia, USA. For Stars in very important to maintain a high score for corruption perception index correlated with a high score of responsible competitiveness.

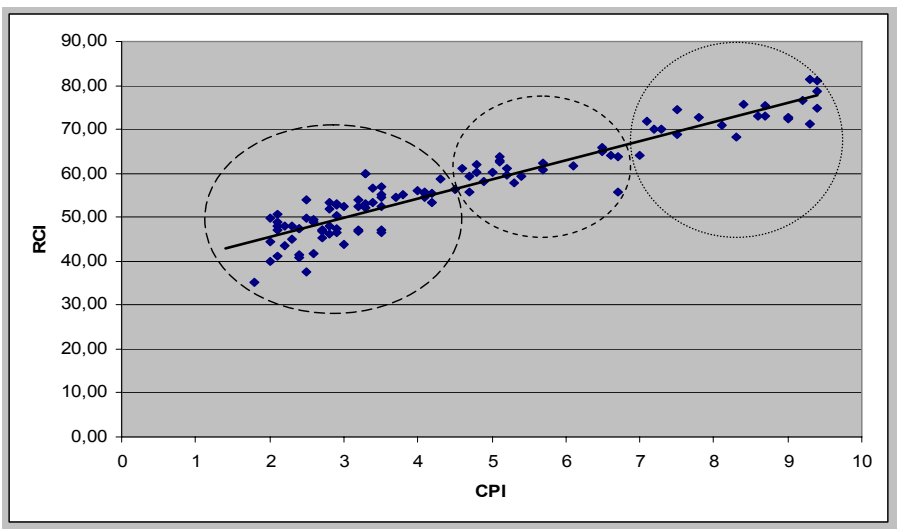

Fig. 2 Identifying clusters of countries by Responsible Competitiveness and Corruption Perception Index 
In recent years, a consensus has emerged across the globe on the high costs of corruption for economic, political, and social development. There has also been broad agreement on an approach to combating corruption that focuses on limiting the discretionary powers of state officials to intervene in the economy. As a result, the fight against corruption in the transition countries has been incorporated into a wider reform agenda combining liberalization and privatization to roll back the state and governance reforms to promote greater transparency and accountability in the state's legal and regulatory framework. However, the experience of the first decade of transition in reducing corruption has been decidedly mixed. Efforts to reform basic state institutions have generally had limited impact (See The Level and Pattern of Corruption in the Transition Countries, World Bank, working paper). Anticorruption campaigns have been hijacked for narrow political advantage. Governance reforms have frequently been blocked by powerful vested interests. The political will to implement and sustain structural reforms has often been lacking. This experience suggests that, although we may know a great deal about the causes and consequences of corruption, we know much less about the factors underlying the persistence of corruption.

\section{References:}

* Christian Ketels, European Clusters, Structural Change in Europe 3 - Innovative City and Business Regions, Hagbarth Publications, 2004.

* Ketels, Christian, Solvell, Orjan, Clusters in the EU-10 new member countries.

* Michael Porter, Clusters and Competition, On competition, Harvard Business School Press, 2008.

* Zadek, Simion, The State of Responsible Competitiveness, AccountAbility, 2007.

* Transparency International, Poverty and Corruption, working paper, no. 2, 2008.

* Transparency International, Report on the Global Corruption Barometer, 2007.

* World Bank, The Level and Pattern of Corruption in the Transition Countries, working paper.

* www.weforum.org - World Economic Forum

* www.transparency.org - Transparency International

* www.accountability21.net 